\title{
Use of accelerator mass spectrometry for studies in nutrition
}

\author{
George S. Jackson ${ }^{1}$, Connie Weaver ${ }^{2}$ and David Elmore ${ }^{1 *}$ \\ ${ }^{1}$ Department of Physics, Purdue University, West Lafayette, IN 47907, USA \\ ${ }^{2}$ Department of Foods and Nutrition, Purdue University, West Lafayette, IN 47907, USA
}

Accelerator mass spectrometry (AMS) is an ultrasensitive analytical technique for measuring rare nuclides such as ${ }^{14} \mathrm{C},{ }^{26} \mathrm{Al}$ and ${ }^{41} \mathrm{Ca}$. The low detection limit and wide dynamic range of AMS allow long-term and highly sensitive tracer studies in nutrition that cannot be performed with other methods. The present paper is intended to provide a description of AMS to the interested nutritionist and present proven applications. AMS is compared to liquid scintillation counting and stable isotope MS. A description of common AMS methodology is presented that consists of determining the dose, preparing the sample, diluting the sample (if necessary), and measuring the sample. Applications include $\mathrm{Ca}$ metabolism, $\mathrm{Al}$ uptake from the environment, dietary intake of carcinogens, fat metabolism and folate metabolism. Throughout this discussion the experimental advantages (small doses that pose no health risk, extremely long experimental lifetime, small sample sizes and high sensitivity) made possible by the unique analytical capabilities of AMS are emphasized. The future of AMS is discussed. As the number of AMS centres, instruments, and studies increases, the number of nutritional applications that employ AMS will continue to grow. The coupling of AMS with other analytical techniques (e.g. high performance liquid chromatography) will be developed as access to AMS improves.

\section{Accelerator mass spectrometry: Stable isotopes: Micronutrient metabolism: Fat metabolism: Carcinogens: Radioisotope}

\footnotetext{
Abbreviations: AMS, accelerator mass spectrometry; ETH/PSI, Eidgenössische Technische Hochschul/Paul Scherrer Institute Ion Beam Physics Department; LSC, liquid scintillation counting; MeIQx, 2-amino-3, 8-dimethyl[2-14C]imidazo[4,5-f]quinoxaline; PhIP, 2-amino-1-methyl-6-pheylimidazo[4,5- $b$ ]bypyridine; PRIME Lab, Purdue Rare Isotope Measurement Laboratory.

*Corresponding author: Professor David Elmore, fax +1 765496 7228, email elmore@ purdue.edu
} 


\section{Introduction}

Isotope tracers are proven and widely used tools for studies of animal metabolism, pharmacokinetics, and biomolecular interactions. Isotope labels provide essentially chemically exact analogues of almost any compound. In nutrition studies, tracer methodology allows the fate of a mineral or labelled compound in the food supply to be followed and its absorption and metabolism to be determined in human subjects or animals after introduction into body pools.

Accelerator mass spectrometry (AMS) provides the most sensitive measurements and lowest detection limits of any isotopic measurement technique for the radionuclides ${ }^{3} \mathrm{H},{ }^{10} \mathrm{Be},{ }^{14} \mathrm{C}$, ${ }^{26} \mathrm{Al},{ }^{36} \mathrm{Cl},{ }^{41} \mathrm{Ca},{ }^{59} \mathrm{Ni},{ }^{99} \mathrm{Tc}$ and ${ }^{129} \mathrm{I}$. With the exception of ${ }^{3} \mathrm{H}$ (half-life 12.25 years), these radionuclides have half-lives in the range $10^{3}-10^{7}$ years. These radioisotopes are very rare in natural materials. AMS is not limited by the relatively small dynamic range possible for stable isotopes nor the low efficiency for decay counting of long-lived radionuclides. The potential for AMS to make advances in biomedicine and nutrition has come to the fore in recent years. Several successful applications have been described in review articles and research reports (Elmore \& Phillips, 1987; Vogel et al. 1990, 1995; Vogel \& Turteltaub, 1992, 1994, 1998; Davis, 1994; Liu et al. 1994; Freeman \& Vogel, 1995; Flarend \& Elmore, 1997; King et al. 1997b; Barker \& Garner, 1999; Fifield, 1999; Jackson et al. 2000a,b).

Radioisotopes may be measured with liquid scintillation counting (LSC). LSC measures decays, so it is not the most efficient means to measure radioisotopes that have longer halflives. AMS counts individual atoms of radioisotopes, making AMS a very efficient technique for counting rare radioisotopes with longer half-lives. Stable isotopes may be measured using a variety of techniques with MS being the most common. MS is able to differentiate between the different mass:charge ions produced by different isotopes in molecules. Ions may be produced by a variety of ionization techniques including thermal ionization, fast atom bombardment and inductively coupled plasma. The relative merits of all of these techniques will be discussed in the following section.

\section{Advantages of accelerator mass spectrometry}

For $\mathrm{H}, \mathrm{C}, \mathrm{Cl}$, and $\mathrm{Ca}$ there are two or more stable isotopes. Stable isotopes pose no health risk and can be processed in normal food processing or handling facilities. However, some drawbacks are associated with stable isotopes. They are expensive. The analysis of stable isotopes can be laborious (compared with LSC) and costly, since stable isotopes are relatively abundant in the environment. Thus, the tissue being analysed must be significantly enriched relative to the measurement precision to provide meaningful data. Stable isotopes may be measured by neutron activation analysis, various mass spectrometric techniques with a variety of ion sources, or Mossbauer spectroscopy. Relative to stable isotopes, radioisotopes are cheap and the analysis is easy (if measured by LSC) and sensitive. The decay of radioisotopes renders them easy to analyse (usually by LSC) but confers other limitations on their use. Experiments must be planned around the production schedule of the isotopes and/or preparation of the labelled compounds or tissues. Regulatory issues with radioisotopes can be quite laborious since they pose a potential health risk and their handling is restricted to approved laboratories (Weaver, 1988; Rennie, 1999; Patterson \& Veillon, 2001).

As mentioned, the sensitivity for stable isotopes is limited by their relatively high abundance in all natural materials. For example, ${ }^{13} \mathrm{C}$ is $1 \%$ abundant so that ${ }^{13} \mathrm{C}$-labelled compounds are not distinguishable from natural carbon when diluted by about five orders of magnitude. 
Natural modern ${ }^{14} \mathrm{C}$ is only about $10^{-10} \%$ abundant and, therefore, if measured by AMS, has a potential dynamic range far greater than ${ }^{13} \mathrm{C}$.

While ${ }^{14} \mathrm{C}$ has a potential dilution range of 12 orders of magnitude, the useful sensitivity is constrained on one side by the dose (limited by cost, radiation damage, and waste disposal) and on the other side by the efficiency of detection. Since AMS counts individual ${ }^{14} \mathrm{C}$ atoms (as opposed to decays) it has a detection efficiency that is $10^{3}-10^{5}$ times greater than conventional decay counting. Decay counting is so inefficient that measuring $0 \cdot 1 \%$ of ${ }^{14} \mathrm{C}$ in a $1 \mathrm{mg}$ sample requires uninterrupted counting for 8.3 years. One study found that AMS provides superior mass (5.5 v. 54000 amol) detection limits relative to LSC for a particular set of samples (Gilman et al. 1998). This improved detection efficiency makes AMS ideal for studies requiring high sensitivity. In addition, for many studies the dose can be so low that there is negligible radiation damage and no waste disposal problems. The dose is typically only a fraction of the total radiation already present in the body. For example, a $73 \mathrm{~kg}$ adult human volunteer already has $3.33 \mathrm{kBq}{ }^{40} \mathrm{~K}$ and $1.85 \mathrm{kBq}{ }^{14} \mathrm{C}$, and many AMS studies require doses of less than $370 \mathrm{~Bq}$. Since the dose is so small, the cost of the labelled compound is usually not significant. Furthermore, the sample needs to only contain approximately $1 \mathrm{mg}$ of the element of interest. Samples that contain as little as $10 \mu \mathrm{g}$ of the element of interest can be measured if carrier (material that is depleted in the radioisotope to be measured) is added.

Some of the advantages of AMS are derived directly from the long half-lives ( $>5000$ years) of many of the rare isotopes that are measured. For example, there is no need to plan around the production schedule of the isotope. Also, the long half-life coupled with the wide dynamic range made possible by AMS allows one to follow the fate of a tracer for years (as opposed to weeks for stable or short-lived isotopes). In many cases the fate of the tracer may be followed for the lifetime of the subject. This greatly improves kinetic modelling and allows one to follow perturbations through change (lifestyle, treatments, growth, etc) without multiple dosing.

The amount of labelled compound needed for a dose is estimated from the product of (1), the fraction that survives or is metabolized into the compound being measured; (2), the fraction that is recovered in the sample collected; (3), the efficiency for extraction from the sample, for example, by HPLC; (4), the efficiency of the AMS measurement. For example, suppose we want ${ }^{41} \mathrm{Ca}:{ }^{40} \mathrm{Ca}$ to be approximately $10^{-10}$ in a given sample. We know that approximately $0.01 \%$ of the dose will appear in our biological sample that contains $5 \mathrm{mg} \mathrm{Ca}$. This corresponds to $7 \cdot 5 \times 10^{9}$ atoms ${ }^{41} \mathrm{Ca}$. Since this is $0.01 \%$ of our dose, we want $7 \cdot 5 \times 10^{13}$ atoms of ${ }^{41} \mathrm{Ca}$ in our dose. Therefore, we should dose the subject with $16 \cdot 7 \mathrm{kBq}{ }^{41} \mathrm{Ca}$. Usually, in AMS it is preferred for samples to have an isotope ratio that is between $10^{-9}$ and $10^{-14}$. The upper end of this range is preferred since these samples can be measured faster. However, samples that are too 'hot' (i.e. have an isotope ratio that is too high) could contaminate the ion source. If the sample is 'hot,' it may be necessary to dilute it with carrier (material of known isotopic abundances that is depleted with respect to the isotope that is being measured).

After the subject is dosed, the samples (blood, urine, tissue, faeces etc) are collected. Once the samples are collected, the next step is to extract the element of interest $(\mathrm{C}, \mathrm{Ca}, \mathrm{Al})$ and prepare it as a compound (target material) that produces a good beam current in the ion source (see the discussion in the next section). Finally the isotope ratio is measured with AMS (e.g. ${ }^{14} \mathrm{C}:{ }^{12} \mathrm{C}$ ). For some projects knowing just the isotope ratio might be enough. However, if determining the absolute amount of tracer in the sample is important, then the concentration of the element being measured has to be determined. Atomic absorption spectroscopy is a common way to determine concentration for many minerals. For some ${ }^{14} \mathrm{C}$-labelled samples, the amount of $\mathrm{C}$ in the sample may be measured by combusting the sample and measuring the sample manometrically. Another method is isotope dilution (Reamer \& Veillon, 1983). In this method a 
spike enriched in a naturally occurring stable isotope is added to the sample. Since the natural levels of the stable isotopes and the ratio of the isotopes in the spike are known, it is possible to determine the amount of analyte originally present in the sample. The Purdue Rare Isotope Measurement Laboratory (PRIME Lab) performs isotope dilutions with ${ }^{36} \mathrm{Cl}\left(\mathrm{a}{ }^{35} \mathrm{Cl}\right.$ spike is used) and ${ }^{14} \mathrm{C}$ (a ${ }^{13} \mathrm{C}$ spike is used). The spike serves as an internal standard. With this methodology, quantitative recovery of the analyte is unneccesary and both isotope ratios can be measured during the same AMS analysis. A flowchart of a typical AMS experiment is shown in Fig. 1.

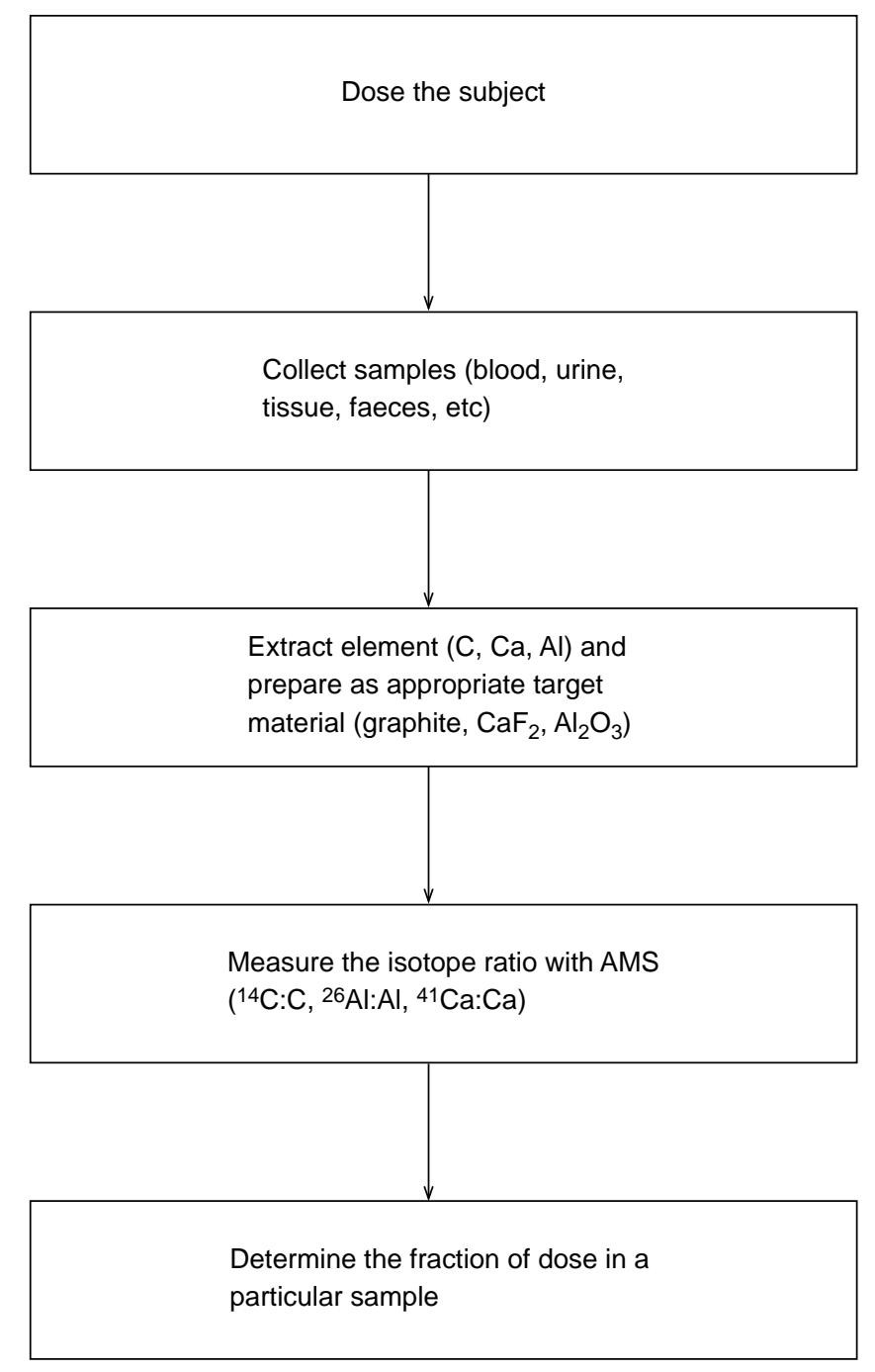

Fig. 1. A flowchart depicting a typical nutritional accelerator mass spectrometry (AMS) experiment. First the subject is dosed. Next the appropriate samples are collected and the appropriate chemistry is performed to prepare the samples for AMS analysis. After the samples are prepared, the isotope ratio is measured by AMS and, in some cases, the fraction of the dose that was in a particular sample is determined. 


\section{Accelerator mass spectrometry methodology}

In this section, the techniques used at PRIME Lab's AMS facility will be described. These techniques are typical of most AMS facilities.

Preparation for AMS analysis requires the production of the appropriate chemical and physical form for the target material to be placed in the ion source. Target materials for the radionuclides analysed by PRIME Lab are listed in Table 1 . The production of graphite for ${ }^{14} \mathrm{C}$ analysis involves drying the original sample by lyophilization or vacuum centrifugation, combustion, addition of carrier (optional), and graphitization. The production of $\mathrm{CaF}_{2}$ for ${ }^{41} \mathrm{Ca}$ analysis involves crude separation of $\mathrm{Ca}$ from the sample material (for example, in urine $\mathrm{Ca}$ oxalate $\left(\mathrm{CaC}_{2} \mathrm{O}_{4}\right)$ is precipitated out), chromatographic clean up, and precipitation as fluoride. The production of $\mathrm{Al}_{2} \mathrm{O}_{3}$ for ${ }^{26} \mathrm{Al}$ analysis involves the addition of carrier since $\mathrm{Al}$ is of low concentration in most biological samples, digestion, and ashing to produce the oxide. After the target material is prepared, it is pressed into a small hole on the end of a short metal rod (cathode). The cathodes are then attached to a circular cassette (sample wheel) that holds eight cathodes. Most AMS ion sources have sample wheels with more cathodes, and PRIME Lab is planning to upgrade its current set up (Kieser et al. 1996; Koslowsky et al. 1997). The wheel is then placed under vacuum in the ion source of the AMS.

AMS combines techniques from magnetic sector MS and nuclear physics. A schematic of PRIME Lab's instrument is shown in Fig. 2. A beam of negative molecular and atomic ions is

Table 1. Common target materials and performance parameters for Purdue Rare Isotope Measurement Laboratory's accelerator mass spectrometer

\begin{tabular}{|c|c|c|c|c|}
\hline Nuclide & Chemical form & Sample size $(\mathrm{mg})^{*}$ & Precision $(\%)^{\dagger}$ & Detection limit $\left(10^{-15}\right)$ \\
\hline${ }^{10} \mathrm{Be}$ & $\mathrm{BeO}$ & 1 & 3 & 5 \\
\hline${ }^{14} \mathrm{C}$ & C (graphite) & 0.5 & 1 & 2 \\
\hline${ }^{26} \mathrm{Al}$ & $\mathrm{Al}_{2} \mathrm{O}_{3}$ & 1 & 7 & 10 \\
\hline${ }^{36} \mathrm{Cl}$ & $\mathrm{Agcl}^{3}$ & 4 & 3 & 0.5 \\
\hline${ }^{41} \mathrm{Ca}$ & $\mathrm{CaF}_{2}$ & 1 & 5 & $1000^{\ddagger}$ \\
\hline $129 \mid$ & $\mathrm{Agl}^{2}$ & 1 & 5 & 20 \\
\hline
\end{tabular}

${ }^{*}$ The minimum detectable amount of rare isotope is the product of the sample size and detection limit, and ranges from a few attograms to a picogram.

tPrecision is quoted for samples above $10^{-12}$ atom/atom. There is a trade-off among sample size, precision, cost, and isotope ratio.

†This detection limit is sufficient for most nutritional applications; however, work is currently ongoing to improve ${ }^{41} \mathrm{Ca}$ capabilities.

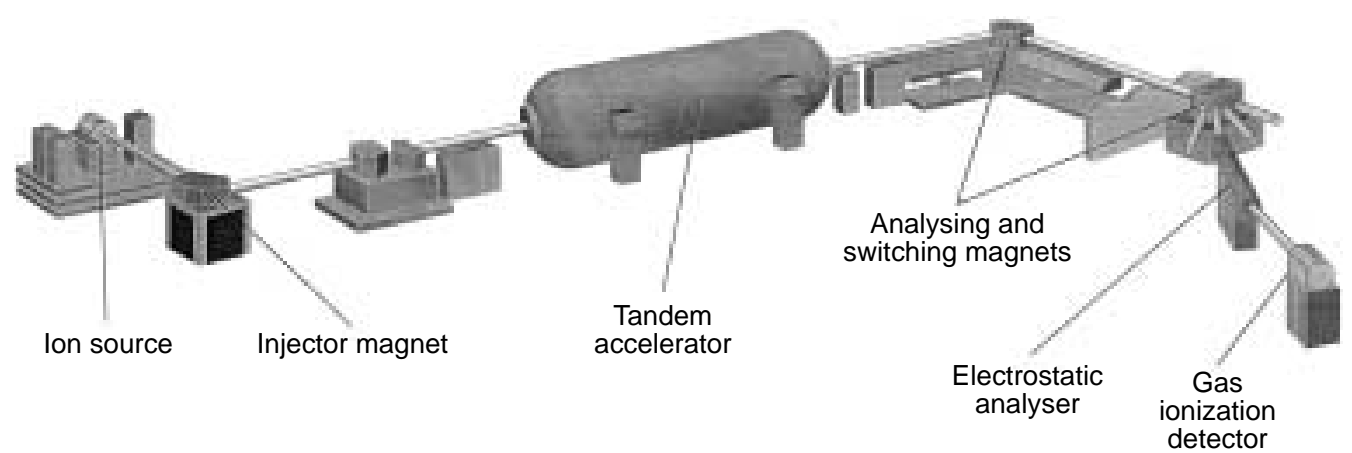

Fig. 2. A schematic of the accelerator mass spectrometer used at Purdue Rare Isotope Measurement Laboratory. 
produced from the target material in the ion source and mass analysed to approximately one atomic mass unit resolution. Ions are attracted to a solid foil or gas collision cell at high potential $(1-10 \mathrm{MeV})$. As the ions pass through the foil or gas, two or more electrons are removed and the atomic and molecular ions become positively charged. The ions are then accelerated away from the positive potential. A relatively abundant charge state (e.g. 3+ at $4 \mathrm{MeV}$ for C) is selected by another mass analyser. Removal of this many electrons has destroyed all molecules. Only atomic ions at high energies (10-100 MeV) are left and their individual properties allow for unique identification with an appropriate detector. The destruction of molecular isobars and unique identification of atomic isobars are the main reasons AMS has such a low detection limit. The size and complexity of these instruments can be rather daunting. The PRIME Lab AMS shown in Fig. 2 is approximately $60 \mathrm{~m}$ from one end to the other. However, a new generation of relatively inexpensive and smaller AMS instruments are being designed (Hughey et al. 1997; Mous et al. 1997; Suter et al. 1997; Jacob et al. 2000; Synal et al. 2000). For example, National Electrostatics Corporation, in collaboration with Eidgenössische Technische Hochschul/Paul Scherrer Institute Ion Beam Physics Department (ETH/PSI), has developed a compact radiocarbon AMS system based on the $500 \mathrm{kV}$ tandem Pelletron. This particular instrument has a footprint of approximately $30 \mathrm{~m}^{2}$. The cost of such an instrument is usually around \$1 million, putting it in the same price range as an NMR spectrometer or a Fourier Transform mass spectrometer. Fortunately, most researchers don't have to buy their own instrument. Most AMS facilities will chemically prepare and measure samples for the scientific community at large. There are over thirty AMS facilities in existence worldwide. Turnaround for samples can range from a few weeks to several months and the cost for analysis and chemical preparation of a sample is typically a few hundred dollars. By way of comparison, the cost for measurement of the stable isotopes of $\mathrm{Ca}$ can range from $\$ 50$ to $\$ 150$ per sample. The cost for measurement of ${ }^{13} \mathrm{C}$ is about $\$ 20$ per sample. Any extra cost for sample analysis by AMS may be offset by savings when purchasing the dose material.

\section{Nutritional applications of accelerator mass spectrometry}

AMS has been used to help elucidate several problems of nutritional importance. The study of $\mathrm{Ca}$ metabolism is important since it comprises our structural frame. Many stable isotopes $\left({ }^{42} \mathrm{Ca}\right.$, ${ }^{43} \mathrm{Ca}$, and ${ }^{44} \mathrm{Ca}$ ) and radioisotopes $\left({ }^{45} \mathrm{Ca}\right.$ and $\left.{ }^{47} \mathrm{Ca}\right)$ are used to study $\mathrm{Ca}$ metabolism. However, it is not feasible to do long-term studies in human subjects with these isotopes due to high cost, unnecessary radiation risks, and the inability to dose high enough to measure beyond 2 weeks. Higher doses are non-physiological, risk perturbing the system, and still cannot be measured long term. ${ }^{41} \mathrm{Ca}$ and AMS overcome these shortcomings by enabling studies to be carried on for years with administration of a small dose. Lack of a suitable tracer has retarded our understanding of the role $\mathrm{Al}$ plays in the body. AMS fills this void with ${ }^{26} \mathrm{Al}$. Finally, radiocarbon and other isotopes can be incorporated into organic compounds without affecting chemical behaviour. AMS has been able to measure food-borne ${ }^{14} \mathrm{C}$ toxins and nutrients at physiological doses. All of these exciting developments will be discussed in the remainder of the paper.

\section{${ }^{41}$ Ca as a tracer for calcium metabolism}

Living bone constantly exchanges $\mathrm{Ca}$ with the rest of the body. This serves two purposes. First, bone can constantly remodel itself for optimal support of the body and repair of microfracture 
damage to the skeleton throughout life. Normally, remodelling replaces approximately $15 \%$ of the bone per year. Second, bone contains $99 \%$ of the body's $\mathrm{Ca}$ and serves as a reserve for homeostasis. Bone $\mathrm{Ca}$ formation and resorption (loss from the bone) are closely linked. However, a slight imbalance in favour of resorption can cause a loss of $\mathrm{Ca}$ from the bone, leading to a loss of bone mass. A simplified version of Ca metabolism showing this imbalance is shown in Fig. 3. The difference between the amount of $\mathrm{Ca}$ consumed and excreted is quite small and difficult to measure. However, radioisotopes of Ca provide good tracers for these experiments. ${ }^{45} \mathrm{Ca}$ has a short half-life $(164 \mathrm{~d})$ and the high doses required for LSC experiments are limiting. The capability of detecting ${ }^{41} \mathrm{Ca}\left(\mathrm{t}_{1 / 2} 1.04 \times 10^{5}\right.$ years $)$ at high sensitivity with AMS has the advantage of allowing long-term studies with no radiation risk. One study was able to measure ${ }^{41} \mathrm{Ca}$ :Ca with AMS 3 years after the approximately $407 \mathrm{~Bq}$ dose was given (Johnson et al. 1994). In fact, measurements could be made for the lifetime of a labelled subject. This ability to measure the tracer for a long period of time has enormous implications for future studies. Bone resorption and turnover could be monitored through life changes (menopause, pregnancy and lactation, etc), environmental changes (space travel, exercise), and therapy (diet, exercise, drugs) for age-related bone loss. One could add therapies until bone resorption was reduced. For example, a person diagnosed with osteopaenia (the precursor to osteoporosis) or osteoporosis could try different therapies (supplements, oestrogen replacement therapy, bisphosphonate, etc) until there was a measured reduction in bone resorption.

The feasibility of ${ }^{41} \mathrm{Ca}$ as a nutritional tracer was first studied in dogs. The ${ }^{41} \mathrm{Ca}$ measurements were made as part of a larger study that used ${ }^{45} \mathrm{Ca}$ to determine the effect of dietary $\mathrm{Cd}$ on $\mathrm{Ca}$ metabolism in dogs. It was shown that ${ }^{41} \mathrm{Ca}$ correlated well with the ${ }^{45} \mathrm{Ca}$ measurements

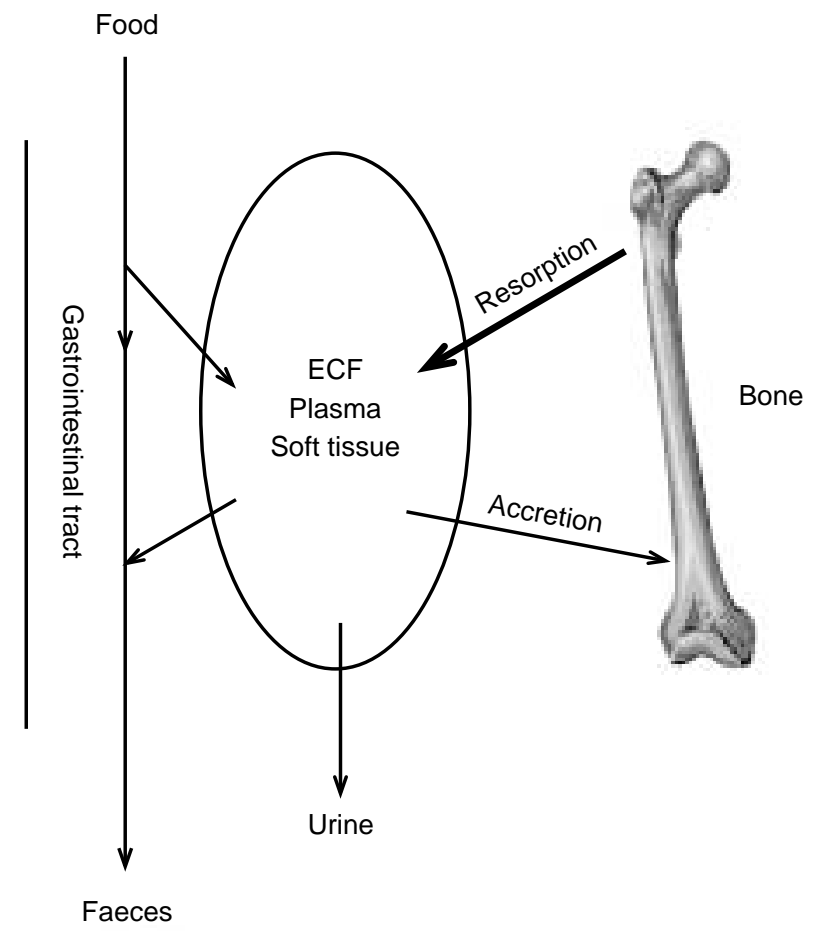

Fig. 3. A scheme for Ca metabolism showing an imbalance; i.e. bone resorption is higher than accretion. ECF, extracellular fluid. 
for the period that ${ }^{45} \mathrm{Ca}$ was measurable (28 weeks). This study demonstrated that ${ }^{41} \mathrm{Ca}$ had the potential to be measured for years after the dose. Finally, a two order of magnitude sensitivity improvement was shown for ${ }^{41} \mathrm{Ca}$ over ${ }^{45} \mathrm{Ca}$ in terms of the number of atoms used in the doses. The potential for an eight order of magnitude sensitivity improvement was discussed (Elmore et al. 1990). The first report of a human subject being dosed was published in 1994 (Johnson et al. 1994). The $407 \mathrm{~Bq}$ dose (the calculated overall radiation dose commitment for the first year is a factor of 30000 times smaller than the total dose from natural radiation) was followed for over $900 \mathrm{~d}$ with measurements in the urine and serum. It was found that the isotopic ratios in the serum samples were similar to those in the urine samples. This is consistent with fast exchange of $\mathrm{Ca}$ between the serum and the urine in the kidneys. Furthermore, the measured ${ }^{41} \mathrm{Ca}$ :Ca reached what the authors refer to as a 'quasi-steady' state after approximately $100 \mathrm{~d}$ with a value of $1.5 \times 10^{-11}$. They conjecture that variations in this signal would signify a change in Ca resorption from the bone. A set of data points was taken in short time intervals 400-500 d after the dose was injected. This was done to observe possible fluctuations relative to the baseline. It was found that random variations over the error bars did exist and it was conjectured that these were perhaps related to menstrual cycle phases, since the subject was asked to hold other factors (diet, exercise, etc) constant (Johnson et al. 1994). This research group recently upgraded their AMS by installing a high-intensity multi-sample ion source and a highresolution Wien filter in the high-energy transport line, to make more efficient and precise ${ }^{41} \mathrm{Ca}$ measurements for future studies of Ca metabolism (Johnson et al. 1999).

Recently, work has been done to develop this methodology further and make these measurements more amenable for the biological community. One of the big steps in this direction was development of an easier-to-prepare target material. A target material that produces a molecular ion that is not formed by the potential interfering isobar ${ }^{41} \mathrm{~K}$ is necessary. $\mathrm{CaH}_{2}$ and $\mathrm{CaF}_{2}$ fulfil this requirement. Initially, samples were prepared as $\mathrm{CaH}_{2}$. The advantages of the hydride are that it produces an intense ion beam in the Cs sputter ion source, and it has an optimal efficiency for transmission through the accelerator. However, the preparation of hydride from sample material is arduous and involves the reduction of $\mathrm{CaO}$ to $\mathrm{Ca}$ metal, followed by conversion to the hydride, requiring technology not common to biochemistry laboratories. Also, once prepared the very hygroscopic hydride has to be kept dry (Fink et al. 1990). Thus, $\mathrm{CaF}_{2}$ is now being used as an alternative to the hydride. In this procedure $\mathrm{Ca}$ is separated from the sample (for example in urine, it can be precipitated out as calcium oxalate $\left(\mathrm{CaC}_{2} \mathrm{O}_{4}\right)$ ). The sample is then re-dissolved, chromatographically cleaned, and precipitated out as $\mathrm{CaF}_{2}$ (Freeman et al. 1995). $\mathrm{CaF}_{2}$ produces a less intense ion beam and has poorer accelerator transmission efficiency, but is still adequate for the higher isotope ratios measured in biological samples. Chemical preparation of the hydride would not be feasible when hundreds of samples are involved.

Further work has been done to determine the feasibility of this technique in human subjects. In one experiment, twenty-five human subjects were each labelled orally with $185 \mathrm{~Bq}$ ${ }^{41} \mathrm{Ca} .{ }^{41} \mathrm{Ca}$ :Ca was measured in urine. The signals showed short-term stability and remarkable response to therapy. The effect of treatment of the anti-resorptive drug alendronate is shown in Fig. 4. Also shown in Fig. 4 is the response of the N-teleopeptide degradation product biomarker normalized to urine creatine content. The response of the biochemical marker has much more scatter than the AMS measurement of ${ }^{41} \mathrm{Ca}$ :Ca (Freeman et al. 2000). Fig. 5 shows data from a subject who was dosed with $37 \mathrm{kBq}{ }^{41} \mathrm{Ca}$ at Purdue University that has been fitted with the equation:

$$
k_{1} \times e^{-k_{2} t}+k_{3} \times t^{-k_{4}}
$$




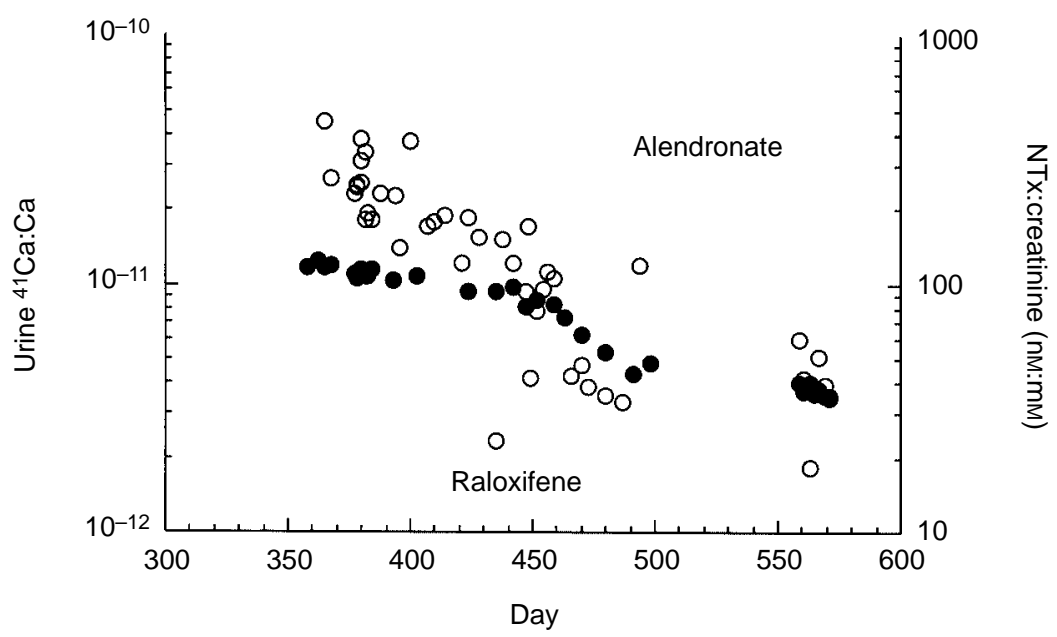

Fig. 4. An individual receiving anti-osteoporosis treatment after $185 \mathrm{~Bq}{ }^{41} \mathrm{Ca}$ was consumed $(\bullet)$. The signal is more stable than the $\mathrm{N}$-teleopeptides collagen degradation product (NTx; $)$ ), normalized to creatine content. Also, a greater response is shown for the drug that significantly decreases resorption (alendronate) than a drug that works by another mechanism (raloxifene). (Reprinted from Freeman et al. (2000) with permission from Elsevier Science.)

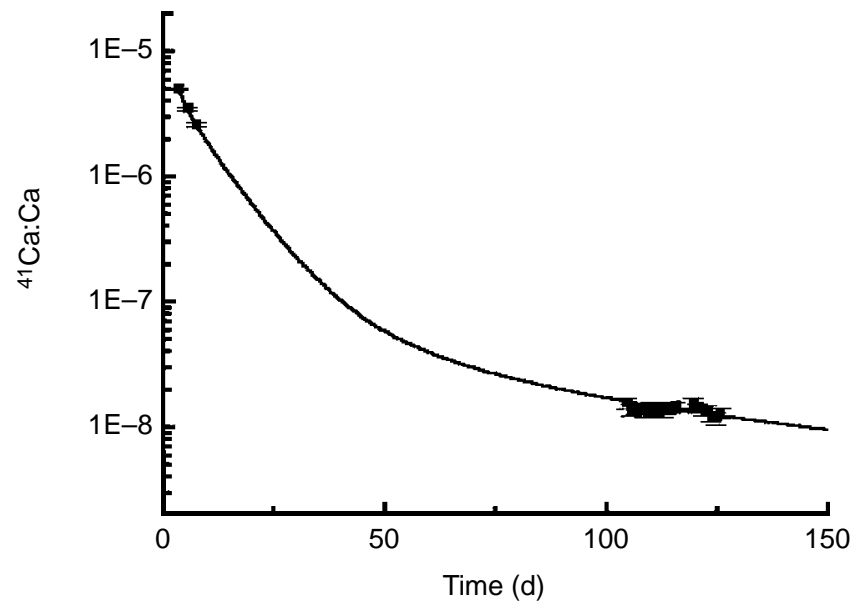

Fig. 5. Preliminary data from the measurement of ${ }^{41} \mathrm{Ca}$ in urine samples. The subject was dosed with $37 \mathrm{kBq}{ }^{41} \mathrm{Ca}$.

where $k_{1}, k_{2}, k_{3}$, and $k_{4}$ are adjustable parameters and $t$ is time. This equation mimics elimination and retention of ${ }^{41} \mathrm{Ca}$ (Carr et al. 1973). Treatment perturbs the prediction. The data in Fig. 5 show the result for one of eleven post-menopausal women labelled with $37 \mathrm{kBq}{ }^{41} \mathrm{Ca}$ at Purdue University as part of a preliminary study. Even with no improvements to our current detection limit for ${ }^{41} \mathrm{Ca}$, it would take 27 years for the signal to decline to the point that it is within one order of magnitude of our baseline! In future studies these women will be given a smaller dose of ${ }^{41} \mathrm{Ca}$ since $37 \mathrm{kBq}$ is more than is necessary. 
As this technique becomes more developed, AMS measurement of ${ }^{41} \mathrm{Ca}$ in urine promises to be the gold standard for determination of bone resorption because it is a direct measure, more precise than previous methods, model-independent, rapid, and non-invasive. One of the research projects in a new Purdue University botanicals centre will use AMS measurements of the ${ }^{41} \mathrm{Ca}: \mathrm{Ca}$ ratios in the urine to determine the effect of isoflavones from soyabean, red clover leaf and flower extracts, and kudzu on bone resorption. From previous studies it is clear that the effect of alendronate has plateaued after $50 \mathrm{~d}$ (Fig. 4). Thus, seven treatments can be tested in the same women in 2 years with 50-d treatments given in randomized order separated by 50-d washout periods. Power calculations show that differences in magnitude one-third as great as that for alendronate (Fig. 4) could be determined with $99 \%$ power in nine women. This technique could be used to measure the impact of any diet or therapy on bone resorption.

\section{${ }^{26}$ Al as a tracer for bioavailability}

The possible neurotoxicity of $\mathrm{Al}$ at environmental levels has heightened interest in the metabolism of Al. Knowledge of chemical and physiological factors that affect Al bioavailability and retention is relatively sparse. Studies with stable $\mathrm{Al}\left({ }^{27} \mathrm{Al}\right)$ are not very sensitive since concentrations in the blood are very low and contamination by $\mathrm{Al}$ in the environment is a problem. Of the three longest-lived isotopes of $\mathrm{Al},{ }^{26} \mathrm{Al}\left(\mathrm{t}_{1 / 2} 716000\right.$ years), ${ }^{28} \mathrm{Al}\left(\mathrm{t}_{1 / 2} 2 \cdot 2 \mathrm{~min}\right.$ ), and ${ }^{29} \mathrm{Al}$ $\left(\mathrm{t}_{1 / 2} 6.6 \mathrm{~min}\right)$, only ${ }^{26} \mathrm{Al}$ can be used for a study of $\mathrm{Al}$ retention over a reasonable time period. It has been shown that with ${ }^{26} \mathrm{Al}$ and AMS the radiation dose for the body can be one order of magnitude or more lower than the daily natural dose rate of radiation for measurement by AMS (Kislinger et al. 1997). AMS is an invaluable tool for studying Al absorption and kinetics.

Before the advent of ${ }^{26} \mathrm{Al}$ measurements by AMS, gallium $(\mathrm{Ga})$ was often used as a surrogate for $\mathrm{Al}$ in biological studies. AMS measurements have shown that ${ }^{67} \mathrm{Ga}$ is a good surrogate for cell culture studies (Dobson et al. 1998), but is not to be trusted in metabolism studies with rats or human subjects (Radunovic et al. 1994; Priest et al. 1995). Thus, ${ }^{26} \mathrm{Al}$ is an invaluable tool in metabolism studies.

Fig. 6 shows a physiological model for Al metabolism. Only a small fraction of the Al that is ingested is absorbed and then it may be excreted or transferred to various tissues from which it can be remobilized. Many groups have measured the bioavailability (also known as the gastrointestinal absorption or uptake factor), $F_{1}$ (defined below) using ${ }^{26} \mathrm{Al}$ and $\mathrm{AMS}$.

$$
F_{1}=\frac{\mathrm{Al}_{\text {absorbed }}}{\mathrm{Al}_{\text {ingested }}} .
$$

Several ways exist to calculate $F_{1}$. The most common way is to take the highest measured plasma concentration, multiply it by the total amount of plasma in the subject and report that as $F_{1}$ (Day et al. 1991, 1994; Edwardson et al. 1993). Inherent uncertainties exist in this measurement. First, the plasma concentration passes through a sharp maximum value and is unlikely to be well defined by a single measurement. Also, uptake of $\mathrm{Al}$ and excretion take place simultaneously in the plasma compartment. Thus, this method sets a lower limit for $F_{1}$. Another method to measure $F_{1}$ is the urinary excretion method. In this method $F_{1}$ is calculated by measuring the ${ }^{26} \mathrm{Al}$ excreted in the urine for a given time period and dividing it by the given dose (King et al. 1997a; Priest et al. 1998). The main problem with this method is that it underestimates $F_{1}$ as well, since some ${ }^{26} \mathrm{Al}$ is retained in the tissues for relatively long time periods. These two methods have been directly compared in one study and it would seem that the 


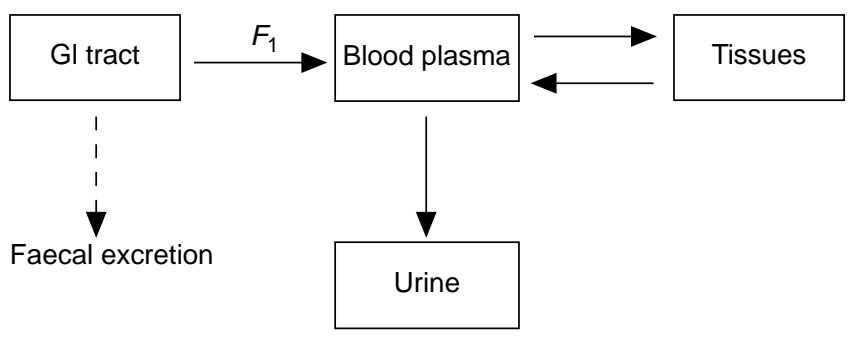

Fig. 6. A scheme depicting aluminium absorption (uptake; $F_{1}$ ), excretion, and retention. Gl, gastrointestinal.

urinary excretion method provides a better estimate of $F_{1}$ since it is approximately a factor of three higher than the plasma peak method on average (King et al. 1997a). This indicates that the urinary excretion method is underestimating $F_{1}$ by a smaller amount. Priest et al. (1998) used the urinary excretion method and attempted to correct their value for the fraction that was thought not to be excreted during their experiment. They corrected by measuring the amount of an intravenous dose that was voided in the urine during the same time period. Another method of calculating $F_{1}$ utilizes the ratio of ${ }^{26} \mathrm{Al}$ in tissue or plasma for an oral dose to that for an intraperitoneal or intravenous dose (Zafar et al. 1997). The bioavailability may also be determined with compartmental modelling. The number of compartments used and the number of samples analysed are the limiting factors of this method (Ritschel, 1992).

The value of $F_{1}$ or the effectiveness of excretion depends on the speciation of the $\mathrm{Al}$ in plasma. Most Al is bound to the Fe carrier protein transferrin. A small amount is bound to the protein albumin or low molecular mass ligands such as citrate and phosphate. It is assumed that the kidneys more easily filter the low molecular weight component and excrete it into the urine (Flarend \& Elmore, 1997; King et al. 1997a). This is why much of the work done to determine the bioavailability of Al has involved citrate and orange juice. Tap water has also been studied extensively since it is a probable source of Al in our diet (Priest et al. 1998; Yokel et al. 2001). Table 2 summarizes some oral dose experiments with human subjects. All the values for $F_{1}$ in Table 2 that involve more than one subject are mean values.

Table 2. Oral dose studies with human subjects

\begin{tabular}{|c|c|c|c|c|c|}
\hline$n$ & Group type & Dose type & $F_{1} \times 10^{3}$, method & Al ingested & Reference \\
\hline 2 & Normal & $\mathrm{AlCl}_{3}$ & $\begin{array}{l}1 \cdot 7, \text { computer } \\
\text { modelling }\end{array}$ & $100 \mu \mathrm{g}$ & Hohl et al. (1994) \\
\hline 5 & Control for Si & Orange juice & $0 \cdot 15$, plasma peak & $\begin{array}{l}70 \mathrm{ng} \text {, carrier- } \\
\text { free }\end{array}$ & Edwardson et al. (1993) \\
\hline 5 & Experimental & $\begin{array}{l}\text { Orange juice } \\
\text { and silicate }\end{array}$ & 0.02 , plasma peak & $\begin{array}{l}70 \mathrm{ng} \text {, carrier- } \\
\text { free }\end{array}$ & Edwardson et al. (1993) \\
\hline 6 & $\begin{array}{l}\text { Control for } \\
\text { Down's } \\
\text { syndrome }\end{array}$ & Orange juice & 0.091, plasma peak & $100 \mu \mathrm{g}$ & Day et al. (1994) \\
\hline 6 & $\begin{array}{l}\text { Down's } \\
\text { syndrome }\end{array}$ & Orange juice & 0.47 , plasma peak & $100 \mu \mathrm{g}$ & (Day et al. 1994) \\
\hline 1 & Normal & Citrate & 10, plasma peak & $1 \cdot 1 \mu \mathrm{g}$ & Day et al. (1991) \\
\hline 2 & Normal & Tap water & $\begin{array}{l}2 \cdot 2 \text {, urinary } \\
\text { excretion }\end{array}$ & $\mathrm{n} / \mathrm{a}$ & Priest et al. (1998) \\
\hline
\end{tabular}

n/a, not applicable. 
Interest in silicate abounds because of Birchall's hypothesis, which predicts that silicate would reduce the bioavailability of $\mathrm{Al}$ in the gastrointestinal tract and promote renal elimination (Edwardson et al. 1993; King et al. 1997a). Indeed a lower value for $F_{1}$ was measured when orange juice was ingested with silicate (Edwardson et al. 1993). The effect of silicate on Al absorption when administered orally with different citrate concentrations has been measured. Two healthy human males were each administered ${ }^{26} \mathrm{Al}$ twice. One of the subjects was administered his dose in two low citrate concentration drinks $(4 \mathrm{mmol} / \mathrm{l})$ that were low in silicate for one dose $(30 \mu \mathrm{mol} / \mathrm{l})$ and high in silicate for the other $(540 \mu \mathrm{mol} / \mathrm{l})$. The other subject was administered his dose in two high citrate concentration drinks $(50 \mathrm{mmol} / \mathrm{l})$ that had the same two silicate concentrations as the other subject. It was found that citrate markedly enhanced bioavailability and that silicate increased the rate of $\mathrm{Al}$ elimination. This increase in elimination was due to an increase in the low molecular weight plasma fraction. Bioavailability was only slightly affected by the presence of silicate. The mean $F_{1}$ calculated by the urinary excretion method was $2 \cdot 1 \times 10^{-3}$ (King et al. 1997a). The use of a tracer such as ${ }^{26} \mathrm{Al}$ is of great benefit to studies that involve citrate since citrate's propensity to bind ions in bodily fluids can spuriously elevate values when concentrations of those ions in the serum and urine are measured directly (Heaney, 2000).

Al bioavailability has also been measured in rats. Bioavailability was found to be $4 \times 10^{-4}$ for rats that were given water or citrate solution orally (Jouhanneau et al. 1993). A value of $F_{1}$ of $9 \cdot 7 \times 10^{-3}$ was determined by measuring the ratio of dose measured in the tissue after oral administration to the dose measured in the tissue after intraperitoneal administration (Zafar et al. 1997). A recent study with twenty-one rats determined $F_{1}$ under conditions that model its consumption in drinking water. It was found that water hardness and the presence or absence of food in the stomach had no impact on $F_{1}$. The uptake factor itself ranged from $2.5 \times 10^{-2}$ to 4 $\times 10^{-2}$ (Yokel et al. 2001).

The range in bioavailability $\left(10^{-5}\right.$ to $\left.10^{-2}\right)$ is due to the method used to calculate bioavailability, the form of the dose, and inter-subject variability. Each individual method of calculating the absorption factor has its own set of uncertainties. The form of the dose will have an impact on $F_{1}$ (citrate, for example, will increase the measured value of $F_{1}$ ). Finally, inter-subject variability plays a role as well. Six healthy male volunteers were given an intravenous injection of ${ }^{26} \mathrm{Al}$ as citrate to compare the rates of $\mathrm{Al}$ elimination from the body. It was found that after $5 \mathrm{~d}$ the whole body retention of the subjects ranged from 16 to $36 \%$ with a mean of 27 (SD 7) \%. The authors believe that this points to a likelihood of large inter-subject differences in the long-term accumulation of dietary $\mathrm{Al}$ by populations receiving the same level of daily intake (Talbot et al. 1995). One experiment eschewed the measurement of $F_{1}$ and broke the distribution of $\mathrm{Al}$ in plasma into four separate compartments. This was done to more fully develop Al biokinetics. It was found that the sizes of the two compartments were different in patients with renal failure when compared with those of healthy volunteers (Kislinger et al. 1997). In the future, compartmental modelling may yield more information than determination of bioavailability. It should be noted that the partial sampling performed in these experiments (serum, urine) leads to partial kinetic models. Full compartmental modelling in human subjects requires collection of blood, urine, and faeces on a controlled diet. In animal models other tissues may contribute even more information.

\section{Tissue studies and Alzheimer's disease}

Rats and mice have been used in tracer studies with ${ }^{26} \mathrm{Al}$ since it is possible to measure $\mathrm{Al}$ absorption in tissue. All of the studies with rats and mice have found ${ }^{26} \mathrm{Al}$ is retained in a 
similar decreasing order in the tissues (bone>kidney>liver>brain; Kobayashi et al. 1990; Jouhanneau et al. 1993; Fink et al. 1994; Radunovic et al. 1994; Walker et al. 1994; Zafar et al. 1997). Much of the work with rats has focused on brain tissue because of the possible role $\mathrm{Al}$ plays in Alzheimer's disease (senile dementia) (Yokel, 2000). The partitioning of Al between the liver and the brain was measured with ${ }^{26} \mathrm{Al}$ and it was found that $\mathrm{Al}$ was seven times more likely to be found in the liver (Fink et al. 1994). One group found that the concentration of $\mathrm{Al}$ in the blood of rats decreased steadily over a 270 - $\mathrm{d}$ period, but after $5 \mathrm{~d}$ the ${ }^{26} \mathrm{Al}$ concentration in the brain remained constant (Yumoto et al. 1995, 1997). This indicates that Al could accumulate in the brain over a long time period.

\section{Carcinogens}

${ }^{14} \mathrm{C}$ is the most generally useful isotope for nutritional studies. The detection limit of AMS has made it possible to study carcinogens in vivo at doses that are at the environmental level. In the first study of this type, AMS was used to determine the amount of carcinogen 2-amino-3,8dimethyl[2-14C]imidazo[4,5-f]quinoxaline (MeIQx) covalently bound (for example by measuring the amount of DNA adducts formed) to mouse liver DNA. MeIQx is formed in cooked muscle meat. Even though MeIQx is a toxin rather than a nutrient, it is used as an example of a compound of dietary origin. The authors report a one order of magnitude improvement over the best DNA adduct detection sensitivity reported at the time and 3-5 orders of magnitude improvement over other methods used to measure adduct formation (Turteltaub et al. 1990). Adduct formation of MeIQx with albumin and haemoglobin was studied. Albumin and haemoglobin were chosen since blood proteins can make good biomarkers because collection of blood is relatively non-invasive. Human volunteers were given $21 \cdot 3$ or $228 \cdot 0 \mu \mathrm{g}\left[{ }^{14} \mathrm{C}\right] \mathrm{MeIQx}$. For reference, $21 \cdot 3 \mu \mathrm{g}$ MeIQx corresponds to the amount of MeIQx typically consumed in a 1 week period. Thus, this was a physiologically relevant dose. The results of the human studies were compared with a study done with rats. It was found that dose-dependent levels of all adducts were found in human subjects and rats (Dingley et al. 1998). In another study with human subjects and rats MeIQx formed adducts at low levels; the human colon was more sensitive to the effects of MeIQx than rats or mice (Mauthe et al. 1999). In a proof-of-principle experiment, radiocarbon $\left({ }^{14} \mathrm{C}\right)$-labelled MeIQx and ${ }^{3} \mathrm{H}$-labelled, 2-amino-1-methyl-6-phenylimidazo[4,5b]bypyridine (PhIP) were used to demonstrate low-level ${ }^{3} \mathrm{H}$ and ${ }^{14} \mathrm{C}$ detection in nutritional samples with AMS. PhIP, like MeIQx, can be found in cooked meat. Researchers were able to differentiate between the two adducts (MeIQx and PhIP) formed with rat liver DNA based on their labels (Dingley et al. 1998). The strengths and weaknesses of AMS and other analytical techniques for DNA adduct determination have been discussed in a recent review (Phillips et al. 2000).

The heterocyclic amine, carcinogen PhIP has been the subject of more AMS research. Human exposure to PhIP is in the parts per billion level from cooked meat. The concentration of $\mathrm{PhIP}$ in the meat ranges from 0 to $70 \mu \mathrm{g} / \mathrm{g}$ meat. Six male mice were administered $\mathrm{PhIP}$ at a dose equivalent to the consumption of two $100 \mathrm{~g}$ beef patties. This is in contrast to previous work where the dose was $10^{4}$ to $10^{6}$ times greater than human dietary exposure levels. It was found that the biological half-life of PhIP was in the order of $1 \mathrm{~h}$ and $90 \%$ of the heterocyclic amine was excreted via the urine. Peak tissue concentration was reached within $3 \mathrm{~h}$ (Turteltaub et al. 1993). The excretion of PhIP into the breast milk of lactating rats and the ability of chlorophyllin, a food product derivative, to affect the levels of PhIP and its metabolites has been analysed with ${ }^{14} \mathrm{C}$ AMS. It was found that chlorophyllin caused increased PhIP levels in 
the milk and stomach contents of the pups. However, the presence of chlorophyllin decreased the PhIP levels in the mammary tissue and blood of the dam, as well as the pups' liver tissue (Mauthe et al. 1998). The ability to study trace organics in our food supply at physiologically relevant doses is a boon for the nutritional scientist.

\section{Folate metabolism}

AMS has also been used to study folate metabolism with a human volunteer. Folate is a generic term given to compounds that have nutritional properties similar to folic acid. Recent evidence has linked low folate concentrations in the plasma with cancer, heart disease and neural tube birth defects. In this study a 57-year-old, healthy, male volunteer was given a physiological (35 $\mu \mathrm{g}, 3 \cdot 7 \mathrm{kBq}$ ) oral dose of $\left[{ }^{14} \mathrm{C}\right]$ folic acid. ${ }^{14} \mathrm{C}$-labelled folate levels were measured in the serial plasma, erythrocytes, urine and faeces taken over a 202-d period. It should be noted that all of the samples and waste were classified as non-radioactive. Further, it was calculated that the subject received a lifetime-integrated dose of only $11 \mu \mathrm{Sv}$, the same dose received during a 2-h transcontinental plane flight. It was shown that $\left[{ }^{14} \mathrm{C}\right]$ folate appeared in the plasma after $10 \mathrm{~min}$ and peaked after 1-2 h, but did not appear in the erythrocytes for $5 \mathrm{~d}$. This showed that mature erythrocytes do not incorporate folate. Folic acid is incorporated during a stage of erythropoiesis (process of production of erythrocytes). It was suggested that this provides a simple clinical test for defective erythropoiesis based on the rapid clearance of the folate from the plasma and the 5-d delay in appearance of labelled erythrocytes. A single drop of blood provides enough material for testing by AMS. This study provides the foundation for targeted cellular studies by AMS with other nutrients (Buchholz et al. 1999a).

\section{Fat metabolism}

Fat metabolism has been studied using human volunteers. Three volunteers (subjects A-C) were given $74 \mathrm{kBq}\left[{ }^{14} \mathrm{C}\right]$ triolein followed by $100 \mathrm{ml}$ of a meal that contained $20 \mathrm{~g}$ fat. Another volunteer (subject D) was given 50 times less $\left[{ }^{14} \mathrm{C}\right]$ triolein in order to test the detection limit of AMS. This subject was tested again 8 months later in order to test the reproducibility of the results. The ${ }^{14} \mathrm{C}$ was measured in expired $\mathrm{CO}_{2}$ after the ingestion of the triolein. AMS enabled long-term measurements (samples were taken for $363 \mathrm{~d}$ ) to be taken from subjects A-C. The results indicated that $30 \%$ of the dose was expired in the first $24 \mathrm{~h}$ and very slow turnover of the fat took place after that. The results from subject D indicated that much smaller doses could be given in the future (Stenström et al. 1996). One could foresee using a similar methodology to explore the impact of various diets on fat metabolism.

\section{${ }^{14}$ C labelling of plant nutrients}

AMS is an excellent tool for defining in vivo metabolism of compounds at physiological concentrations. To investigate the metabolism of nutrients that are an intrinsic part of our diet, plants have been grown in ${ }^{14} \mathrm{CO}_{2}$-enriched environments. Such generic photosynthetic labelling of plants can provide labelled compounds that are hard to produce synthetically. In an attempt to do this, spinach and kale were grown in an atmospherically sealed chamber with ${ }^{14} \mathrm{CO}_{2}$ to produce labelled carotenoids and folates. The folate material in the kale did not incorporate 
enough of the label to be considered useful for human studies. However, the labelling of carotenoids in the spinach was a success (AJ Clifford, personal communication). $\beta$ $\left[{ }^{14} \mathrm{C}\right]$ carotene was extracted from the spinach and a physiological oral dose $(7 \cdot 4 \mathrm{kBq}, 0 \cdot 57$ $\mu \mathrm{mol})$ was given to a human volunteer. Serial blood, urine, and faeces samples were collected for 210,17 , and $10 \mathrm{~d}$ respectively. The sample was $42 \%$ bioavailable, since $58 \%$ of the dose was collected in 48 -h faeces. The absorbed $\beta$-carotene and its metabolites were lost slowly via urine due to the low aqueous solubility and long biological half-lives of these compounds (Dueker et al. 2000).

\section{${ }^{14} \mathrm{C}$ depletion and concentration in animals}

The absolute sensitivity for biological samples is limited by the natural ${ }^{14} \mathrm{C}$ present in all biological material (the current or 'contemporary' ${ }^{14} \mathrm{C}:{ }^{12} \mathrm{C}$ in the environment is about $1385 \times$ $10^{-15}$ as opposed to $<10^{-15}$ for ${ }^{26} \mathrm{Al}$ and ${ }^{41} \mathrm{Ca}$ ). To overcome this limitation, mice have been fed a diet containing mainly yeast protein that was depleted with respect to ${ }^{14} \mathrm{C}$. After one generation these mice had $20 \%$ of the ${ }^{14} \mathrm{C}$ level presently found in biological matter (Turteltaub et al. 1993). In practice this would give a factor of five in improvement in the detection limit for any nutritional research with these mice that employed uptake of ${ }^{14} \mathrm{C}$-labelled compounds.

Another approach is to enrich the animal in ${ }^{14} \mathrm{C}$ and perform a nutritional study with the enriched meat or other products from the animal. For example, in one recent study piglets were raised to market weight with a regular regimen of intravenous injections of $\left[{ }^{14} \mathrm{C}\right]$ proline. One piglet received 20 weekly injections of $370 \mathrm{kBq}\left[{ }^{14} \mathrm{C}\right]$ proline in its lateral ear vein. This resulted in a dose of $7400 \mathrm{kBq}$ and since $9250 \mathrm{kBq}$ labelled proline only cost $\$ 417$, the cost of labelling was minimal. Small-intestinal submucosa (SIS) was harvested from the pigs and was found to be 4000 times greater than the contemporary ${ }^{14} \mathrm{C}:{ }^{12} \mathrm{C}$. SIS is being used as a biological scaffold (Rickey et al. 2000). However, one could foresee a similar labelling strategy being used to trace meat or specific labelled compounds isolated from the meat in diets for nutritional studies.

\section{Future directions}

One of the most obvious future directions will be the growth of programmes devoted to biomedical AMS, such as the one at the Center for Accelerator Mass Spectrometry (or CAMS) at Lawrence Livermore National Laboratory (Davis, 1994) and the one at PRIME Lab (Jackson et al. 2000). Further, the Center for Biomedical Accelerator Mass Spectrometry (or CBAMS, Ltd.) is the first fully commercial AMS facility in the world. As the name would imply, they are marketing heavily toward pharmaceutical and biotechnology industries (Barker \& Garner, 1999). As the utility of and power of AMS becomes better realized, additional companies will offer biomedical AMS measurements to their clientele.

Many of the current AMS instruments are quite expensive and have quite a large footprint (the PRIME Lab AMS in Fig. 2 is approximately $60 \mathrm{~m}$ long). However, a new generation of relatively inexpensive and smaller AMS instruments are being designed (Hughey et al. 1997; Mous et al. 1997; Suter et al. 1997; Jacob et al. 2000; Synal et al. 2000). As mentioned, National Electrostatics Corporation in collaboration with ETH/PSI is now marketing small AMS instruments.

AMS provides no structural information. However, coupled with an appropriate separation technique, AMS can be a very powerful tool for quantifying labelled metabolites. Recently, 
off-line HPLC has been used in several studies with AMS (Buchholz et al. 1999; Mauthe et al. 1999b; Dueker et al. 2000). PRIME Lab is currently involved in a collaboration to study the metabolism of vitamin $\mathrm{B}_{6}$ and a large part of this collaboration is the measurement of HPLCseparated vitamin $\mathrm{B}_{6}$ metabolites. Of course, AMS could be used with any separation technique (GC, capillary electrophoresis, etc) to provide this information. It is certain that elegant nutritional studies will take advantage of this in the future.

\section{References}

Barker J \& Garner RC (1999) Biomedical applications of accelerator mass spectrometry-isotope measurements at the level of the atom. Rapid Communications in Mass Spectrometry 13, 285-293.

Buchholz BA, Arjomand A, Dueker SR, Schneider PD, Clifford AJ \& Vogel JS (1999a). Intrinsic erythrocyte labeling and attomole pharmacokinetic tracing of ${ }^{14} \mathrm{C}$-labeled folic acid with accelerator mass spectrometry. Analytical Biochemistry 269, 348-352.

Buchholz BA, Fultz E, Haack KW, Vogel JS, Gilman DS, Gee SJ, Hammock BD, Hui X, Wester RC \& Maibach HI (1999b) HPLC-accelerator MS measurement of atrazine metabolites in human urine after dermal exposure. Analytical Chemistry 71, 3519-3525.

Carr TEF, Harrison GE \& Nolan J (1973) The long-term excretion and retention of an intravenous dose of ${ }^{45} \mathrm{Ca}$ in two healthy men. Calcified Tissue Research 12, 217-226.

Davis JC (1994) AMS beyond 2000. Nuclear Instruments and Methods in Physics Research 92B, 1-6.

Day JP, Barker J, Evans LJA, Perks J, Seabright PJ, Ackrill P, Lilley JS, Drumm PV \& Newton GWA (1991) Aluminum absorption studied by ${ }^{26} \mathrm{Al}$ tracer. Lancet 337, 1345.

Day JP, Barker J, King SJ, Miller RV, Templar J, Lilley JS, Drumm PV, Newton GWA, Fifield LK, Stone JOH, Allan GL, Edwardson JA, Moore PB, Ferrier IN, Priest ND, Newton D, Talbot RJ, Brock JH, Sánchez L, Dobson CB, Itzhaki RF, Radunovic A \& Bradbury MWB (1994) Biological chemistry of aluminum using ${ }^{26} \mathrm{Al}$ and accelerator mass spectrometry. Nuclear Instruments and Methods in Physics Research. 92B, 463-468.

Dingley KH, Freeman SPHT, Nelson DO, Garner CR \& Turteltaub KW (1998). Covalent binding of 2-amino-3,8dimethylimidazo[4,5-f]quinoxaline to albumin and hemoglobin at environmentally relevant doses. Drug Metabolism and Disposition 26, 825-828.

Dingley KH, Roberts ML, Velsko CA \& Turteltaub KW (1998). Attomole detection of ${ }^{3} \mathrm{H}$ in biological samples using accelerator mass spectrometry: application in low-dose dual-isotope tracer studies in conjunction with ${ }^{14} \mathrm{C}$ accelerator mass spectrometry. Chemical Research in Toxicology 11, 1217-1222.

Dobson CB, Day PJ, King SJ \& Itzhaki RF (1998) Location of aluminum and gallium in human neuroblastoma cells treated with metal-chelating agent complexes. Toxicology and Applied Pharmacology 152, 145-152.

Dueker SR, Lin Y, Buchholz BA, Schneider PD, Lame MW, Segall HJ, Vogel JS \& Clifford AJ (2000) Long-term kinetic study of $\beta$-carotene in a human subject using accelerator mass spectrometry in an adult volunteer. Journal of Lipid Research 41, 1790-1800.

Edwardson JA, Moore PB, Ferrier IN, Lilley JS, Newton GWA, Barker J, Templar J \& Day JP (1993) Effect of silicon on gastrointestinal absorption of aluminum. Lancet 342, 211-212.

Elmore D, Bhattacharyya MH, Sacco-Gibson N \& Peterson DP (1990) Calcium-41 as a long-term biological tracer for bone resorption. Nuclear Instruments and Methods in Physics Research 52B, 531-535.

Elmore D \& Phillips FM (1987) Accelerator mass-spectrometry for measurement of long-lived radioisotopes. Science 236, 543-550.

Fifield LK (1999) Accelerator mass spectrometry and its applications. Reports on Progress in Physics 62, $1223-1274$.

Fink D, Middleton R, Klein J \& Sharma P (1990) ${ }^{41}$ Ca: Measurement by accelerator mass spectrometry and applications. Nuclear Instruments and Methods in Physics Research 47B, 79-96.

Fink D, Walton J, Hotchkis MAC, Jacobsen GE, Lawson EM, Smith AM, Tuniz C \& Wilcox D (1994) First ${ }^{26} \mathrm{Al}$ analyses at the Antares AMS Centre: uptake via oral ingestion of ${ }^{26} \mathrm{Al}$ in rats. Nuclear Instruments and Methods in Physics Research 92B, 473-477.

Flarend R \& Elmore D (1997) Aluminum-26 as a tracer using accelerator mass spectrometry. In Aluminum Toxicity in Infants Health and Disease, pp. 16-39 [P Zatta and A Alfrey, editors]. River Edge, NJ: World Scientific Publishing Co.

Freeman SPHT, Beck B, Bierman J, Caffee MW, Heaney RP, Holloway L, Marcus R, Southon JR \& Vogel JS (2000) The study of skeletal $\mathrm{Ca}$ metabolism with ${ }^{41} \mathrm{Ca}$ and ${ }^{45} \mathrm{Ca}$. Nuclear Instruments and Methods in Physics Research 172B, 930-933.

Freeman SPHT, Serfass RE, King JC, Southon JR, Fang Y, Woodhouse LR, Bench GS \& McAninch JE (1995) Biological sample preparation and ${ }^{41} \mathrm{Ca}$ AMS measurement at LLNL. Nuclear Instruments and Methods in Physics Research 99B, 557-561.

Freeman SPHT \& Vogel JS (1995) Biomedical accelerator mass spectrometry. International Journal of Mass Spectrometry and Ion Processes 143, 247-256. 
Gilman DS, Gee SJ, Hammock BD, Vogel JS, Haack K, Buchholz BA, Freeman SPHT, Wester RC, Hui X \& Maibach HI (1998) Analytical performance of accelerator mass spectrometry and liquid scintillation counting for detection of ${ }^{14} \mathrm{C}$-labelled atrazine metabolites in human urine. Analytical Chemistry 70, 3463-3469.

Heaney RP (2000) Factors influencing the measurement of bioavailibility, taking calcium as a model. Journal of Nutrition 131, 13445-13485.

Hohl C, Gerisch P, Korschinek G \& Nolte E (1994) Medical application of ${ }^{26} \mathrm{Al}$. Nuclear Instruments and Methods in Physics Research 92B, 478-482.

Hughey BJ, Klinkowstein RE, Shefer RE, Skipper PL, Tannenbaum SR \& Wishnok JS (1997) Design of a compact 1 MV AMS system for biomedical research. Nuclear Instruments and Methods in Physics Research 123B, 153-158.

Jackson GS, Elmore D, Rickey FA, Musameh SA, Sharma P, Hillegonds D, Coury L \& Kissinger P (2000a) The PRIME Lab Biomedical Program. Nuclear Instruments and Methods in Physics Research 172B, 901-905.

Jackson GS, Rickey FA, Hillegonds D, Rounds MA \& Elmore D (2000b) Attomole measurement of labelled compounds. Current Separations 19, 3-8.

Jacob SAW, Suter M \& Synal H-A (2000) Ion beam interaction with stripper gas-Key for AMS at sub MeV. Nuclear Instruments and Methods in Physics Research 172B, 235-241.

Johnson RR, Berkovits D, Boaretto E, Gelbart Z, Ghelberg S, Meirav O, Paul M, Prior J, Sossi V \& Venczel E (1994) Calcium resorption from bone in a human studied by ${ }^{41} \mathrm{Ca}$ tracing. Nuclear Instruments and Methods in Physics Research 92B, 483-488.

Johnson RR, Berkovits D, Boaretto E, Gelbart Z, Hershkowitz A, Hui SK, Paul M, Prior J \& Venczel E (1999) Upgrading of ${ }^{41} \mathrm{Ca}$ AMS detection and biomedical application. 8th International Conference on Accelerator Mass Spectrometry, Vienna, Austria.

Jouhanneau P, Lacour B, Raisbeck G, Yiou F, Banide H, Brown E \& Drüeke T (1993) Gastrointestinal absorption of aluminum in rats using ${ }^{26} \mathrm{Al}$ and accelerator mass spectrometry. Clinical Nephrology 40, 244-248.

Kieser WE, Litherland AE, Zhao X-L, Kilius LR \& Beukens RP (1996) A high capacity ion source for AMS. Nuclear Instruments and Methods in Physics Research 113B, 461-464.

King SJ, Day JP, Oldham C, Popplewell JF, Ackrill P, Moore PB, Taylor GA, Edwardson JA, Fifield LK, Liu K \& Cresswell RG (1997a) The influence of dissolved silicate on the physiological chemistry of aluminum, studied in humans using tracer ${ }^{26} \mathrm{Al}$ and accelerator mass spectrometry. Nuclear Instruments and Methods in Physics Research 123B, 254-258.

King SJ, Oldham C, Popplewell JF, Carling RS, Day JP, Fifield LK, Cresswell RG, Liu KX \& diTada ML (1997b) Determination of aluminum-26 in biological materials by accelerator mass spectrometry. Analyst 122, 1049-1055.

Kislinger G, Steinhausen C, Alvarez-Brückmann M, Winklhofer C, Ittel T-H \& Nolte E (1997) Investigations of the human aluminum biokinetics with ${ }^{26} \mathrm{Al}$ and AMS. Nuclear Instruments and Methods in Physics Research 123B, $259-265$.

Kobayashi K, Yumoto S, Nagai H, Hosoyama Y, Imamura M, Masuzawa S, Koizumi Y \& Yamashita H (1990) ${ }^{26} \mathrm{Al}$ tracer experiment by accelerator mass spectrometry and its application to the studies for amyotrophic lateral sclerosis and alzheimer's disease. Proceedings of the Japan Academy 66B, 189-192.

Koslowsky VT, Bray N, Imahori Y, Andrews HR \& Davies WG (1997) The new Chalk River AMS ion source, sample changer and external sample magazine. Nuclear Instruments and Methods in Physics Research 123B, $203-207$.

Liu YF, Guo ZY, Liu XQ, Qu T \& Xie JL (1994) Applications of accelerator mass-spectrometry in analysis of trace isotopes and elements. Pure and Applied chemistry 66, 305-334.

Mauthe RJ, Dingley KH, Leveson SH, Freeman SPHT, Turesky RJ, Garner CR \& Turteltaub KW (1999) Comparison of DNA-adduct and tissue-available dose levels of MeIQx in human and rodent colon following administration of a very low dose. International Journal of Cancer 80, 539-545.

Mauthe RJ, Snyderwine EG, Ghoshal A, Freeman SPHT \& Turteltaub KW (1998) Distribution and metabolism of 2amino-1-methyl-6-phenylimidazo[4,5-b]pyridine (PhIP) in female rats and their pups at dietary doses. Carcinogenesis 19,919-924.

Mous DJW, Purser KH, Fokker W, van den Broek R \& Koopmans RB (1997) A compact 14C isotope ratio mass spectrometer for biomedical applications. Nuclear Instruments and Methods in Physics Research 123B, 159-162.

Patterson KY \& Veillon C (2001). Stable isotopes of minerals as metabolic tracers in human nutrition research. Experimental Biology and Medicine 226 271-282.

Phillips DH, Farmer PB, Beland FA, Nath RG, Poirer MC, Reddy MV \& Turteltaub KW (2000) Methods of DNA adduct determination and their application to testing compounds for genotoxicity. Environmental and Molecular Mutagenesis 35, 222-233.

Priest ND, Newton D, Day JP, Talbot RJ \& Warner AJ (1995) Human metabolism of aluminum-26 and gallium-67 as injected citrates. Human and Experimental Toxicology 14, 287-293.

Priest ND, Talbot RJ, Newton D, Day JP, King SJ \& Fifield LK (1998) Uptake by man of aluminum in a public water supply. Human and Experimental Toxicology 17, 296-301.

Radunovic A, Ueda F, Raja K, Day JP, Templar J \& Bradbury MWJ (1994) Uptake of ${ }^{26} \mathrm{Al}$ and ${ }^{67} \mathrm{Ga}$ into tissues of anaesthetized normal and hypotransferrinaemic mice. Journal of Physiology 475P, 154.

Reamer DC \& Veillon C (1983) A double isotope dilution method for using stable selenium isotopes in metabolic tracer studies: Analysis by gas chromatography/mass spectrometry (GC/MS). Journal of Nutrition 113, 786.

Rennie MJ (1999) An introduction to the use of tracers in nutrition and metabolism. Proceedings of the Nutrition Society 58, 935-944. 
Rickey FA, Elmore D, Hillegonds D, Badylak S, Record R \& Simmons-Byrd A (2000) Regeneration of tissue about an animal-based scaffold; AMS studies of the fate of the scaffold. Nuclear Instruments and Methods in Physics Research 172B, 904-909.

Ritschel W.A. (1992) Handbook of Basic Pharmacokinetics - Including Clinical Applications. Hamilton, IL: Drug Intelligence Publications.

Stenström K, Leide-Svegborn S, Erlandsson B, Hellborg R, Sören M, Nillson L-E, Nosslin B, Skog G \& Wiebert A (1996) Application of accelerator mass spectrometry (AMS) for high-sensitivity measurements of ${ }^{14} \mathrm{CO}_{2}$ in long-term studies of fat metabolism. Applied Radiation and Isotopes 47, 417-422.

Suter M, Jacob S \& Synal HA (1997) AMS of ${ }^{14} \mathrm{C}$ at low energies. Nuclear Instruments and Methods in Physics Research 123B, 148-152.

Synal H-A, Jacob S \& Suter M (2000) The PSI/ETH small radiocarbon dating system. Nuclear Instruments and Methods in Physics Research 172B, 1-7.

Talbot RJ, Newton D, Priest ND, Austin JG \& Day JP (1995) Inter-subject variability in the metabolism of aluminum following intravenous injection as citrate. Human and Experimental Toxicology 14, 595-599.

Turteltaub KW, Felton JS, Gledhill BL, Vogel JS, Southon JR, Cafee MW, Finkel RC, Nelson DE, Proctor ID \& Davis JC (1990) Accelerator mass spectrometry in biomedical dosimetry: relationship between low-level exposure and covalent binding of heterocyclic amine carcinogens to DNA. Proceedings of the National Academy of Sciences of the USA 87, 5288-5292.

Turteltaub KW, Vogel JS, Frantz C, Buonarati MH \& Felton JS (1993) Low-level biological dosimetry of heterocyclic amine carcinogens isolated from cooked food. Environmental Health Perspectives 99, 183-186.

Vogel JS \& Turteltaub KW (1992) Biomolecular tracing through accelerator mass spectrometry. Trends in Analytical Chemistry 11, 142-149.

Vogel JS \& Turteltaub KW (1994) Accelerator mass spectrometry in biomedical research. Nuclear Instruments and Methods in Physics Research 92B, 445-453.

Vogel JS \& Turteltaub KW (1998) Accelerator mass spectrometry as a bioanalytical tool for nutritional research. In Mathematical Modeling in Experimental Nutrition, pp. 397-410 [CA Müller, editor]. New York: Plenum Press.

Vogel JS, Turteltaub KW, Felton JS, Gledhill BL, Nelson DE, Southon JR, Proctor ID \& Davis JC (1990) Application of AMS to the biomedical sciences. Nuclear Instruments and Methods in Physics Research 52B, 524-530.

Vogel JS, Turteltaub KW, Finkel R \& Erle Nelson D (1995) Accelerator mass spectrometry: isotope quantification at attomole sensitivity. Analytical Chemistry 67, A353-A359.

Walker VR, Sutton RAL, Meirav O, Sossi V, Johnson R, Klein J, Fink D \& Middleton R (1994) Tissue disposition of ${ }^{26}$ aluminum in rats measured by accelerator mass spectrometry. Clinical and Investigative Medicine 17, 420-425.

Weaver C (1988) Istopic tracer methodology: potential in mineral nutrition. In Trace Minerals in Foods, pp. 429-454 [KT Smith, editor]. New York: Marcel Dekker.

Yokel RA (2000) The toxicology of aluminum in the brain: a review. Neurotoxicology 21, 813-828.

Yokel RA, Rhineheimer SS, Brauer RD, Sharma P, Elmore D \& McNamara PJ (2001) Aluminum bioavailability from drinking water is very low and is not appreciably influenced by stomach contents or water hardness. Toxicology 161, 93-101.

Yumoto S, Kakimi S, Ogawa Y, Nagai H, Imamura M \& Kobayashi K (1995) Aluminum neurotoxicity and Alzheimer‘s disease. In Alzheimer's and Parkinson's Diseases, pp. 223-229 [I Hainin, Yoshida M and Fisher A, editors]. New York: Plenum Press.

Yumoto S, Nagai H, Imamura M, Matsuzaki H, Hayashi K, Masuda A, Kumazawa H, Ohashi H \& Kobayashi K (1997) ${ }^{26} \mathrm{Al}$ uptake and accumulation in the rat brain. Nuclear Instruments and Methods in Physics Research 123B, 279-282.

Zafar TA, Weaver CM, Martin BR, Flarend R \& Elmore D (1997) Aluminum ( $\left.{ }^{26} \mathrm{Al}\right)$ metabolism in rats. Proceedings of the Society for Experimental Biology and Medicine 216, 81-85. 